\title{
The Driving Forces of Stock Returns in Hong Kong
}

\author{
Samuel Xin Liang ${ }^{1}$ \\ ${ }^{1}$ Tyndale Seminary, Tyndale University College and Seminary, Toronto, Ontario Canada \\ Correspondence: Samuel Xin Liang, Tyndale University College and Seminary, Toronto, Ontario M2M 3S4 Canada. \\ E-mail: xin.liang@mytyndale.ca
}

Received: April 8, 2019

Accepted: September 2, 2019

Online Published: September 3, 2019

doi:10.5430/afr.v8n4p1

URL: https://doi.org/10.5430/afr.v8n4p1

\begin{abstract}
We comprehensively investigate what drives stock returns in Hong Kong stock market which has been consistently ranked as one of the most important markets for IPOs. We find that Hong Kong inflation rate is a systematic pricing factor across stocks after controlling for Fama-French three-factor. It is different from the U.S. market and other developed markets that the momentum, dividend yield, cash-flow yield, earnings yield, and return-reversal factors are not significant pricing factors for stock returns in Hong Kong. Our Fama-MacBeath (1973) regressions show that a stock's value (cash-flow yield and book-to-market ratio) is the strongest predictor of stock returns in Hong Kong after controlling for market, value, and size factors and macroeconomic factors.
\end{abstract}

JEL Classification: G11, G12, G15

Keywords: systematic risk factor, inflation rate, pricing premium, cash flow yield, return predictability

\section{Introduction}

Hong Kong has been consistently ranked as one of the most important markets for Initial Public Offerings (IPOs) by dollar value in the past decades. It has been serving global investors as a prominent international financial center and an international trading hub for global goods and services for the Asia Pacific region. Both the International Monetary Fund (IMF) and the International Financial Corporation (IFC) of the World Bank Group classify Hong Kong as a developed economy. Therefore, global investors demand a comprehensive investigation on what drives stock returns in Hong Kong stock market. Economists have developed market equilibrium models and theories that tie macroeconomic variables to risky assets' returns (See Cox, Ingersoll and Ross (1985), Lucas (1978) and Merton (1973)). They suggest that the covariance between macroeconomic variables and asset returns is an important determinant of the latter. Chen, Roll, and Ross (1986) find that in addition to market return, industrial production growth is a significant systematic pricing factor across stocks in the U.S. stock market in the 1958-1984 period. Their study also suggests that unexpected inflation is a negative pricing factor across stocks in the 1968-1977 period. As Hong Kong's currency and its interest rate are tied to the US dollar and its interest rate, global investors would eager to know if industrial production growth and inflation rate are also significant pricing factors for stock returns in Hong Kong stock market. The first task of this paper addresses this asset pricing issue. In the U.S. market, Fama and French (1993) find that besides market excess return, value and size factors are also common pricing factors across stocks. (Note 1) Jegadeesh and Titman (1993) show that the momentum strategy generates significant profits in the U.S. market while Carhart (1997) show that the momentum factor is a significant pricing factor for mutual funds in the USA. Pástor and Stambaugh (2003) also find that liquidity risk is a pricing factor across stocks in the U.S. and Liang and Wei (2012) find that liquidity risk is also a pricing factor for stock returns in Hong Kong. Ang, Hodrick, Xing, and Zhang (2006) find that local market volatility risk factor demands a significant pricing premium across stocks in the U.S. market while, however, Liang and Wei (2019) find that local market volatility risk factor is not a significant pricing factor in Hong Kong stock market. On the other hand, Hou, Karolyi and Kho (2011) find that the cash-flow factor is the only systematic pricing factor across 27,000 stocks in the world market while Liang (2019) also find that the cash-flow factor is a significant pricing factor for stocks in the Japanese stock market. (Note 2) Recently, Liang (2018) theoretically and empirically show that market sentiment shock is a significant behavioral pricing factor for stock returns in the U.S. market. (Note 3) We also examine whether there is any other local market risk factor, in addition to Fama and French's three factors, is also a cross-sectional pricing factor in the Hong Kong stock market. Researchers also have a comprehensive and extensive study on the predictability of stock returns in the US market and the global market as a whole. (Note 4) However, there is not enough comprehensive investigation to 
check what cross-sectionally predict stock returns in Hong Kong stock market as a single market after controlling for significant local market risk factors and macroeconomic factors. (Note 5) The second task of this paper addresses this gap.

We use Fama and Macbeth's (1973) methodology to find that cash-flow yield, earnings yield, dividend yield, leverage yield and return reversal factors are not local systematic risk factors for stock returns in Hong Kong. This is very different the U.S. market and other developed markets such as Japanese stock market. Testing the economic theories and intuition put forth by Cox, Ingersoll and Ross (1985) and Merton (1973), we also use Fama-MacBath (1973) methodology to find that the inflation rate (CPI growth) systematically prices stock returns in the 1980-2013 period in the Hong Kong stock market after controlling for Fama-French's three factors. (Note 6) The pricing premium of the inflation rate is significantly negative because a high inflation rate will lead to a high operating cost for corporations listed in Hong Kong and hence reduce their profitability. Thus, a high inflation rate will reduce the number of opportunities available to investors in the stock market. Our finding is consistent with and supports the pricing of an inflation rate in the U.S. market by Chen, Roll, and Ross (1986).

Puzzlingly, we also find that the unexpected industrial production growth has a significant and negative pricing premium after controlling for Fama and French three factors. Our result on industrial production growth contradicts that of Chen, Roll, and Ross (1986). (Note 7) This result is puzzling because industrial production growth can provide investment opportunities to investors. After thinking deeply, we can interpret this puzzling result that Hong Kong's production growth itself may not be reflected in the stock markets for two reasons. First, Hong Kong Economy changed from manufacturing economy to an international trading and services economy when China opened its economy to international investors in 1978. Second, a large number of Chinese corporations have been listed in the Hong Kong Stock Exchange and become the major components of the Hong Kong stock market.

Investigating the predictability of stock returns as our third task, we use Fama-Macbeth (1973) regressions to show that a stock's value measured by book-to-market ratio and cash-flow yield significantly predicts stock returns after controlling for local market risk factors and macroeconomic factors and that they have the strongest predicting power for stock returns in Hong Kong stock market. This finding on stock return predictability is similar to the cross-sectional predictability of stock returns in China that was documented by Cakici, Chan, and Topyan (2015). This similarity of stock return predictability can be due to the fact that a large number of stocks listed in Hong Kong are Chinese corporations whose economic activities are in China. Our results together with their results also suggest that the underlying fundamentals of stocks and the cheapness of their pricing are critically driving forces for the predictability of stock returns of corporations listed in either Hong Kong Stock Exchange or Shanghai and Shenzhen Stock Exchanges. A stock's fundamental and the cheapness of its pricing are more important than the regulations of stock exchanges and their participants. This is because 1) Hong Kong Stock Exchange has very different regulations from that of Shanghai and Shenzhen Stock Exchanges, 2) Hong Kong Stock market is classified as a developed market while Chinese stock market is classified as an emerging market by Morgan Stanley Capital International (MSCI) and 3) Hong Kong Stock Exchange is opened to global investors while Chinese exchanges are mainly restricted to China's domestic investors.

Our study contributes to the literature in three ways. First, we confirm the pricing implication of macroeconomic factors as suggested by Cox, Ingersoll and Ross (1985) and Merton (1973) and reveal that inflation rate systematically prices stock returns in Hong Kong stock market. Our finding argues global investors to hedge the inflation risk in Hong Kong for their portfolios that include stocks listed in Hong Kong Stock Exchange. Second, we document that the well-known cash-flow yield factor, momentum factor, return-reversal factor, dividend yield factor and earnings yield factor are not systematic pricing factors for stocks in Hong Kong. Our finding suggests global investors to pay more attention to market, value and size factors than other local market risk factors which are important in the US market and other developed markets. Third, we present evidence that a stock's value is the most important predictor of stock returns in Hong Kong because a stock's value measured by book-to-market ratio and cash-flow yield has the strongest predicting power for stocks listed in Hong Kong Stock Exchange. Our findings provide global investors rewarding portfolio-construction strategies by a stock's value. We inform them that the cheap pricing of a stock's fundamentals is the most important predictor of stock returns in their portfolio-constructions in Hong Kong. Our study also provides global investors a comprehensive guidance on what systematic factors price stock returns and what significantly predicts stock returns in Hong Kong. This guiding information helps them to properly manage and hedge systematic risks and construct profitable portfolios for their local, regional and global portfolios that include stocks listed in Hong Kong. 


\section{Theoretical Motivation}

Cox, Ingersoll and Ross (1985) and Merton (1973) suggest that a macroeconomic factor providing a set of opportunities to investors should be a systematic pricing factor across stock returns. Testing their theories, Chen, Roll, and Ross (1986) use Fama-MacBath (1973) methodology to find that inflation rate and industrial production growth are significant systematic pricing factors for stocks in the US market. (Note 8) The industrial production growth reflects the productivity and economic growth of an economy. It should provide opportunities to investors because private corporations are the main drivers of the economic growth and output of an economy. These economic intuitions suggest that industrial production growth should positively price stock returns in a stock market if it is a systematic pricing factor across stocks. However, it is different for inflation rate because a high inflation rate will increase a company's operating costs and hence decreases its profitability. We expect that high inflation rate should reduce the investment opportunities to investors. Therefore, we can economically infer that the inflation rate should negatively price stock returns.

However, there is no study in the literature, which investigates the pricing of industrial production growth and inflation in Hong Kong stock market. The Hong Kong stock market is a global capital market and can be considered as a small proxy for the U.S. market while developed markets in Europe, Japan and China cannot. These economies have different monetary policies and China's stock markets are mainly restricted to domestic investors. (Note 9) We should test whether industrial production growth and inflation rate are systematic pricing factors for stock returns in Hong Kong because its monetary policy is closely tied to the US monetary policy. This is due to the fact that their currencies and interest rates are tied. In our tests for the pricing of these macroeconomic factors, we control for the appropriate local market risk factors.

\section{Data}

The sample period in this paper begins from January 1979 and ends in December 2013 because the number of stocks with valid financial variables is very limited prior to 1979. The total number of active stocks in December 2013 in our sample is 1,614. We download the daily total return index and monthly accounting and financial variables for each stock in the Hong Kong stock market from Datastream. The monthly financial variables are total book equity, net income, market capitalization, dividend per share, depreciation, long-term debt, unadjusted closing price, and shares outstanding. We then construct a stock's characteristics comprising its market capitalization (size), book-to-market ratio (BM), cash-flow yield (OCF), earnings yield (EP), dividend yield (DY), leverage yield (LEV), market beta, return reversal (return for the past one month), momentum, total volatility, and idiosyncratic volatility. We treat the past one-month return as being equivalent to the short-term (return) reversal in Jegadeesh (1990). We use Jegadeesh and Titman's (1993) momentum as the cumulative return for the past six months. The book-to-market ratio (BM) is total book equity divided by total market capitalization as in Fama and French (1992). The cash-flow yield is operating free cash flow per share divided by the unadjusted closing price. The earnings yield is earnings per share divided by the unadjusted closing price. The dividend yield is total dividend in the past twelve months divided by the unadjusted closing price. The leverage yield is the debt-to-equity ratio divided by the unadjusted closing price. We also estimate the total volatility of each stock $i$ as the standard deviation of daily returns $r_{i, t}$ in each month $t$ as follows:

$$
\operatorname{TVOL}_{i, t}=\sqrt{\operatorname{Var}\left(r_{i, t}\right)} \quad .
$$

We then estimate the idiosyncratic volatility $\left(I V O L_{i, t}=\sqrt{\operatorname{Var}\left(\varepsilon_{i, \tau, t}\right)}\right)$ of stock $i$ in month $t$ as the standard deviation of the daily idiosyncratic component $\varepsilon_{i, \tau, t}$ of the following CAPM regression:

$$
r_{i, \tau, t}=\alpha_{i, t}+\beta_{i, t-1} M K T X_{\tau, t}+\varepsilon_{i, \tau, t}, \tau=1, . ., D_{t}
$$

where MKTX is the Hong Kong stock market returns minus the US dollar risk-free rate and $D_{t}$ is the number of days in month $t$.

\subsection{Macroeconomic Factors}

We also download the macroeconomic variables of consumer price index (CPI) and industrial output each quarter from Datastream. We construct the inflation rate (CPI growth) and the growth rate of industrial production. The industrial production growth rate is the percentage growth of industrial production from the last period. We compute the quarterly growth rate and use that as the monthly growth rate within the quarter. This methodology is consistent with the seminal work of Chen, Roll, and Ross (1986) for macroeconomic variables. In section 5, we will investigate whether these two macroeconomic factors systematically price stock returns for the period from 1979 to 2013. 


\subsection{Local Market Risk Factors}

We start off by investigating which of the following local market factors are systematic pricing factors for stock returns in Hong Kong: the market factor $(M K T X)$, value factor, size factor, momentum factor, cash-flow yield risk factor, earnings yield factor, dividend yield factor, leverage yield factor, and short-term reversal factor. We sort all stocks into the top $30 \%$, the middle $40 \%$ and the bottom $30 \%$ based on their book-to-market ratios. The value factor $(H M L)$ is the value-weighted return difference between the top $30 \%$ portfolio and the bottom $30 \%$ portfolio. We also sort all stocks into the top 30\% (big), the middle $40 \%$ and the bottom $30 \%$ (small) based on market capitalization (size). The size factor $(S M B)$ is the value-weighted return difference between the bottom $30 \%$ portfolio and the top $30 \%$ portfolio. MKTX, $H M L$, and SMB are Fama and French's (1992) three factors.

We then sort all stocks into the top 30\% (winners), the middle 40\%, and the bottom 30\% (losers) based on their past 6-month returns. The momentum factor $(M O M)$ is the value-weighted return difference between the bottom $30 \%$ portfolio and the top 30\% portfolio. Next, we sort all stocks into the top 30\%, the middle $40 \%$ and the bottom $30 \%$ based on their cash flow-to-price ratios. The cash-flow yield factor $(O C F)$ is the value-weighted return difference between the top $30 \%$ portfolio and the bottom $30 \%$ portfolio. We then construct the earnings yield factor and dividend yield factor in the same way as the cash-flow yield factor. We also sort all stocks into the top 30\%, the middle $40 \%$, and the bottom $30 \%$ based on their past one-month returns. The short-term reversal factor (Rev) is the value-weighted return difference between the bottom $30 \%$ portfolio and the top $30 \%$ portfolio. Finally, we sort all stocks into the top $30 \%$, the middle $40 \%$ and the bottom $30 \%$ based on their leverage yield. The leverage yield factor (Lev) is value-weighted return difference between the top $30 \%$ portfolio and the bottom $30 \%$ portfolio.

\section{The Systematic Pricing of Local Market Risk Factors}

In this section, we investigate which of the aforementioned local market risk factors, in addition to Fama and French's three factors, systematically price stock returns in Hong Kong. We first assume that these local market risk factors are systematic risk factors and estimate a stock's sensitivity (betas) to these factors. We then sort stocks into five portfolios by these betas and calculate both equal-weighted and value-weighted portfolios. We also form the zero-cost H-L portfolios that long the portfolios with the highest betas and short the portfolios with the lowest betas. We then regress the time-series returns of H-L portfolios on CAPM in order to check if these H-L portfolios can generate significant risk-adjusted excess returns (alphas) in 1980-2013 period. Finally, we use Fama-MacBeth (1973) two-stage methodology to examine whether these local market risk factors are indeed systematic risk factors for stocks in the Hong Kong market. This methodology is the standard testing procedure to test whether a market risk factor is a systematic pricing factor for stock returns. It has been widely used for testing market risk factors in the work of Fama and French(1993), Carhart (1997), Fama and French (1998), Ang, Hodrick, Xing, and Zhang (2006), Hou, Karolyi and Kho (2011), Kubota and Takehara (2017), Liang and Wei (2019) and Liang (2019). We adjust the $t$-statistics according to Newey and West (1987).

\subsection{Profitability of Portfolios Sorted on Betas of Local Market Risk Factors}

We begin by estimating a stock's sensitivity (betas) to the local market risk factors in the following regression (3) using the time-series data for the last five years. The minimum length of the regression period for this estimation is 12 months. The five-year rolling window is the standard procedure to estimate the betas in the literature.

$$
R_{i, \tau}=\alpha_{i, t-1}+\beta_{i, t-1}^{m} M^{\prime} K T X_{\tau}+\beta_{i}^{h} H M L_{\tau}+\beta_{i}^{s} S M B_{\tau}+\beta_{i, t-1}^{l F} \text { LocalFactor }_{\tau}+\varepsilon_{i, \tau}, \quad \tau=t-60, \ldots, t-1,
$$

where $M K T X, H M L$, and $S M B$ are the market factor, value factor and the size factor, and LocalFactor is one of the local market risk factors that are the leverage yield factor, the dividend yield factor, the earnings yield factor, the momentum factor, the cash-flow yield factor, and the short-term reversal factor. We first sort stocks into five portfolios according to their betas $\beta_{i, t-1}^{l F}$ and calculate the equal- and value-weighted portfolio returns for the 1980-2013 period. We then form the zero-cost H-L portfolios that long stocks with the highest betas and short stocks with the lowest betas. As reported in Table 1, the H-L portfolios based on the betas of the momentum factor, the dividend yield factor, the earnings yield factor, the short-term reversal factor, and the leverage yield factor do not generate significantly higher or lower returns in this period. However, the H-L portfolios' value-weighted returns formed on the betas of the cash-flow yield factor do generate significantly positive monthly returns of $0.80 \%$ (t-statistic 2.27) in this period.

This table reports the one-month return and CAPM alphas of portfolios sorted on the betas of local risk factors in 1980-2013. All stocks in are Hong Kong are sorted into five portfolios each month based on the betas, $\beta_{i, t-1}^{L F}$, of local factors. The betas of local factors are estimated as the following. 


$$
R_{i, \tau}=\alpha_{i, t-1}+\beta_{i, t-1}^{m} M K T X_{\tau}+\beta_{i, t-1}^{h} H M L_{\tau}+\beta_{i, t-1}^{s} S M B_{\tau}+\beta_{i, t-1}^{L F} \text { LocalFactor }_{\tau}+\varepsilon_{i, \tau}, \quad \tau=t-60, \ldots, t-1,
$$

LocalFactors are leverage yield factor, dividend yield factor, earnings yield factor, momentum factor, cash-flow yield factor, and short-term reversal factor. We calculate the equal- and value-weighted portfolio returns for both 1979-2013 and 1990-2013 periods. The adjusted t-statistics according to Newey and West (1987) are in parentheses. $*, * *$, and $* * *$ indicate significance at the $10 \%, 5 \%$, and $1 \%$ levels, respectively.

Table 1. Returns of portfolios constructed by the betas of local market factors

\begin{tabular}{|c|c|c|c|c|c|c|}
\hline \multicolumn{7}{|c|}{ Returns of Portfolios sorted on betas of local market risk factors } \\
\hline \multirow[t]{2}{*}{ Portfolio } & \multicolumn{2}{|c|}{ Earnings Yield } & \multicolumn{2}{|c|}{ Cash-Flow Yield } & \multicolumn{2}{|c|}{ Dividend Yield } \\
\hline & ew_ret & $v w_{-} r e t$ & ew_ret & $v w_{-} r e t$ & ew_ret & $v w_{-} r e t$ \\
\hline 1 & 2.06 & 1.17 & 1.80 & 0.82 & 1.83 & 0.88 \\
\hline 2 & 1.88 & 1.16 & 1.79 & 1.17 & 2.08 & 1.28 \\
\hline 3 & 1.75 & 1.19 & 1.51 & 1.17 & 1.42 & 1.13 \\
\hline 4 & 1.70 & 1.59 & 1.81 & 1.21 & 1.71 & 1.50 \\
\hline 5 & 1.70 & 1.36 & 1.97 & 1.63 & 2.04 & 1.29 \\
\hline \multirow[t]{4}{*}{$5-1$} & $-0.36^{*}$ & 0.19 & 0.16 & $0.80 * *$ & 0.21 & 0.41 \\
\hline & $(-1.71)$ & $(0.70)$ & $(0.67)$ & $(2.27)$ & $(0.91)$ & $(1.21)$ \\
\hline & \multicolumn{2}{|c|}{ Leverage Yield } & \multicolumn{2}{|c|}{ Short-term Reversal } & \multicolumn{2}{|c|}{ Momentum } \\
\hline & ew_ret & vw_ret & ew_ret & vw_ret & ew_ret & vw_ret \\
\hline 1 & 1.86 & 1.23 & 2.15 & 0.90 & 1.86 & 1.24 \\
\hline 2 & 1.47 & 1.21 & 1.58 & 1.01 & 1.88 & 1.44 \\
\hline 3 & 1.84 & 1.24 & 1.62 & 1.38 & 1.56 & 1.09 \\
\hline 4 & 1.78 & 1.19 & 1.80 & 1.32 & 1.75 & 1.23 \\
\hline 5 & 1.57 & 0.68 & 1.78 & 1.35 & 1.88 & 0.99 \\
\hline \multirow[t]{2}{*}{$5-1$} & -0.29 & -0.55 & $-0.37 *$ & 0.45 & 0.02 & -0.25 \\
\hline & $(-1.29)$ & $(-1.75)$ & $(-1.80)$ & $(1.68)$ & $(0.09)$ & $(-0.75)$ \\
\hline
\end{tabular}

We proceed to check the risk-adjusted excess returns (alphas) of these portfolios in CAPM and regress the five portfolios and the zero-cost portfolio in the CAPM. As reported in Table 2, we find that the value-weighted zero-cost (5-1) portfolios formed on the betas of the cash-flow yield factor do generate significantly positive alphas in CAPM. However, this result is mainly driven by the low beta portfolio (1) with a beta of $-0.67 \%(t=2.07)$. On the other hand, the zero-cost (5-1) portfolios formed on betas of the leverage yield factor generate significantly negative alphas in CAPM while the alphas of these five portfolios are not monotonically decreasing. However, the zero-cost (5-1) portfolios formed on the earnings yield factor, the dividend yield factor, the momentum factor and the short-term reversal factor cannot generate significant alphas in CAPM. In the following subsection, we employ Fama and Macbeth's (1973) two-stage methodology to perform a more comprehensive test.

This table reports the CAPM alphas of portfolios sorted on the betas of local risk factors in 1980-2013. All stocks in Hong Kong are sorted into five portfolios each month based on the betas, $\beta_{i, t-1}^{L F}$, of local factors. The betas of local factors are estimated as the following.

$$
R_{i, \tau}=\alpha_{i, t-1}+\beta_{i, t-1}^{m} M K T X_{\tau}+\beta_{i, t-1}^{h} H M L_{\tau}+\beta_{i, t-1}^{s} S M B_{\tau}+\beta_{i, t-1}^{L F} \text { LocalFactor }_{\tau}+\varepsilon_{i, \tau}, \tau=t-60, \ldots, t-1,
$$

LocalFactors are leverage yield factor, dividend yield factor, earnings yield factor, momentum factor, cash-flow yield factor, and short-term reversal factor. We calculate the equal- and value-weighted portfolio returns for both 1979-2013 period. The adjusted t-statistics according to Newey and West (1987) are in parentheses. *,**, and *** indicate significance at the $10 \%, 5 \%$, and $1 \%$ levels, respectively. 
Table 2. Alphas of portfolio constructed by betas of local market factors

\begin{tabular}{|c|c|c|c|c|c|c|}
\hline \multicolumn{7}{|c|}{ Alphas of CAPM } \\
\hline \multirow[t]{2}{*}{ Portfolio } & \multicolumn{2}{|c|}{ Earnings Yield } & \multicolumn{2}{|c|}{ Cash-Flow Yield } & \multicolumn{2}{|c|}{ Dividend Yield } \\
\hline & ew_ret & $v w \_r e t$ & ew_ret & $v w \_r e t$ & ew_ret & $v w \_r e t$ \\
\hline \multirow[t]{2}{*}{1} & 0.55 & -0.43 & 0.36 & -0.67 & 0.28 & -0.63 \\
\hline & $(1.47)$ & $(-1.70)$ & $(0.90)$ & $(-2.07)$ & $(0.72)$ & $(-2.17)$ \\
\hline \multirow[t]{2}{*}{2} & 0.52 & -0.11 & 0.45 & -0.19 & 0.70 & 0.02 \\
\hline & $(1.88)$ & $(-0.53)$ & $(1.66)$ & $(-1.23)$ & $(2.59)$ & $(0.11)$ \\
\hline \multirow[t]{2}{*}{3} & 0.55 & -0.13 & 0.49 & 0.05 & 0.28 & -0.17 \\
\hline & $(2.52)$ & $(-0.87)$ & $(2.64)$ & $(0.35)$ & $(1.41)$ & $(-0.93)$ \\
\hline \multirow[t]{2}{*}{4} & 0.40 & 0.21 & 0.60 & -0.02 & 0.42 & 0.15 \\
\hline & $(1.88)$ & $(1.51)$ & $(2.33)$ & $(-0.11)$ & $(1.80)$ & $(1.17)$ \\
\hline \multirow[t]{2}{*}{5} & 0.26 & -0.15 & 0.64 & 0.29 & 0.61 & -0.21 \\
\hline & $(0.79)$ & $(-0.87)$ & $(2.04)$ & $(1.52)$ & $(1.77)$ & $(-1.32)$ \\
\hline \multirow[t]{4}{*}{$5-1$} & -0.29 & 0.29 & 0.28 & $0.96^{* * *}$ & 0.34 & 0.43 \\
\hline & $(-1.35)$ & $(1.03)$ & $(1.14)$ & $(2.72)$ & $(1.47)$ & $(1.25)$ \\
\hline & \multicolumn{2}{|c|}{ Leverage Yield } & \multicolumn{2}{|c|}{ Short-term Reversal } & \multicolumn{2}{|c|}{ Momentum } \\
\hline & $e w \_r e t$ & $v w_{-} r e t$ & $e w \_r e t$ & $v w_{-} r e t$ & $e w \_r e t$ & $v w_{-} r e t$ \\
\hline \multirow[t]{2}{*}{1} & 0.61 & -0.01 & 0.80 & -0.43 & 0.45 & -0.22 \\
\hline & $(1.80)$ & $(-0.05)$ & $(2.28)$ & $(-1.95)$ & $(1.37)$ & $(-0.89)$ \\
\hline \multirow[t]{2}{*}{2} & 0.32 & -0.01 & 0.29 & -0.28 & 0.53 & 0.05 \\
\hline & (1.63) & $(-0.06)$ & $(1.35)$ & $(-1.88)$ & $(2.21)$ & $(0.30)$ \\
\hline \multirow[t]{2}{*}{3} & 0.71 & 0.01 & 0.43 & 0.03 & 0.32 & -0.24 \\
\hline & (3.08) & $(0.07)$ & $(2.28)$ & $(0.24)$ & (1.69) & $(-1.54)$ \\
\hline \multirow[t]{2}{*}{4} & 0.47 & -0.19 & 0.44 & -0.06 & 0.50 & -0.07 \\
\hline & $(1.70)$ & $(-0.85)$ & $(1.81)$ & $(-0.35)$ & $(2.08)$ & $(-0.52)$ \\
\hline \multirow[t]{2}{*}{5} & 0.13 & -0.79 & 0.39 & -0.10 & 0.54 & -0.39 \\
\hline & $(0.36)$ & $(-3.07)$ & (1.19) & $(-0.47)$ & $(1.62)$ & $(-1.62)$ \\
\hline \multirow[t]{2}{*}{$5-1$} & $-0.48 * * *$ & $-0.79 * * *$ & $-0.40 *$ & 0.33 & 0.09 & -0.18 \\
\hline & $(-2.22)$ & $(-2.58)$ & $(-1.94)$ & $(1.24)$ & $(0.45)$ & $(-0.53)$ \\
\hline
\end{tabular}

4.2. Pricing Premiums of Local Market Risk Factors

Fama and Macbeth (1973) outline two-stage regressions to test whether a risk factor systematically prices stock returns and demands a significant pricing premium. This two-stage methodology is the standard procedure for testing whether a factor is a significant pricing factor for stocks. In order to control for Fama and French's three factors, we first estimate the time-series sensitivity (betas) of each stock to these local market risk factors in the following regression using past five-year data:

$$
R_{i, \tau}=\alpha_{i, t-1}+\beta_{i, t-1}^{m} M K T X_{\tau}+\beta_{i, t-1}^{h} H M L_{\tau}+\beta_{i, t-1}^{s} S M B_{\tau}+\beta_{i, t-1}^{l} \text { LocalFactor }_{\tau}+\varepsilon_{i, \tau}, \tau=t-60, \ldots, t-1,
$$

where MKTX, HML and $S M B$ are Fama and French's (1992) three factors. The local market risk factor, LocalFactor, is the leverage yield factor, or the dividend yield factor, or the earnings yield factor, or the momentum factor, or the cash-flow yield factor, or the short-term reversal factor. We then estimate the pricing premiums of these local market risk factors using the following cross-sectional regression:

$$
R_{i, t}=\alpha+\beta_{i, t-1}^{m} \lambda_{m}+\beta_{i, t-1}^{h} \lambda_{h}+\beta_{i, t-1}^{s} \lambda_{s}+\beta_{i, t-1}^{l} \lambda_{l}, \quad t=0, \ldots, T,
$$


where $\lambda_{m}, \lambda_{h}$, and $\lambda_{s}$ are the pricing premiums of $M K T X, H M L$ and $S M B . \lambda_{l}$ is the pricing premium of one of the local market risk factors LocalFactor. $R_{i, t}$ is stock $i$ 's return in month $t$.

As reported in Table 3, we find that size (SMB) and value (HML) are the only significant pricing factors across stocks in Hong Kong. However, the momentum factor, the cash-flow yield factor, the dividend yield factor, the earnings yield factor, the leverage yield factor and the reversal factor do not demand a significant pricing premium. Our results show that the cash-flow yield factor is not a pricing factor across stocks in Hong Kong. This is different from the finding in Hou, Karolyi and Kho's (2011) that the cash-flow yield factor is the only pricing factor across 27,000 stocks in the world stock market and the finding in Liang (2019) that the cash-flow yield factor is a significant pricing factor in Japan. These results show that we should use Fama and French's three-factor model as a base model to test whether macroeconomic factors systematically price stock returns in the Hong Kong stock market. We proceed to do just that in the next section.

This table reports the pricing premium of macroeconomic factors using Fama-Macbeth (1973) methodology. The betas of local market factors, LocalFactor, are estimated from the following regression using past five-year data.

$$
R_{i, \tau}=\alpha_{i, t-1}+\beta_{i, t-1}^{m} M K T X_{\tau}+\beta_{i, t-1}^{h} H M L_{\tau}+\beta_{i, t-1}^{s} S M B_{\tau}+\beta_{i, t-1}^{m} \text { LocalFactor }_{\tau}+\varepsilon_{i, \tau}, \tau=t-60, . ., t-1,
$$

The pricing premium are estimated using the following regression.

$$
R_{i, t}=\alpha+\beta_{i, t-1}^{m} \lambda_{m}+\beta_{i, t-1}^{h} \lambda_{h}+\beta_{i, t-1}^{s} \lambda_{s}+\beta_{i, t-1}^{l} \lambda_{l}, t=0, \ldots, T,
$$

The local market factors are book-to-market factor $(H M L)$, size $(S M B)$, momentum $(M O M)$, cash-flow yield (OCF), dividend yield factor (DY), earnings yield factor (EY), leverage yield factor (Lev), and short-term reversal factor (Rev). The adjusted t-statistics according to Newey and West (1987) are in parentheses. *, **, and *** indicate significance at the $10 \%, 5 \%$, and $1 \%$ levels, respectively.

\begin{tabular}{|c|c|c|c|c|c|c|}
\hline & Model 1 & Model 2 & Model 3 & Model 4 & Model 5 & Model 6 \\
\hline$\lambda^{m}$ & 0.06 & 0.04 & 0.00 & 0.10 & 0.02 & 0.12 \\
\hline & $(0.20)$ & $(0.12)$ & $(0.01)$ & $(0.33)$ & $(0.05)$ & $(0.41)$ \\
\hline$\lambda^{h}$ & $0.25^{* *}$ & 0.13 & 0.18 & 0.18 & $0.21^{*}$ & $0.23 * *$ \\
\hline & $(2.13)$ & (1.17) & (1.58) & (1.53) & (1.87) & $(2.10)$ \\
\hline$\lambda^{s}$ & $0.32 *$ & 0.26 & $0.31 *$ & 0.29 & 0.30 & $0.31 *$ \\
\hline$\lambda$ & (1.72) & $(1.41)$ & (1.66) & $(1.51)$ & $(1.60)$ & (1.66) \\
\hline$\pi_{\text {Mom }}$ & -0.12 & - & - & - & & \\
\hline$\lambda_{O C F}$ & $(-0.63)$ & -0.03 & & & & \\
\hline$\lambda_{D Y}$ & & $(-0.15)$ & 0.12 & - & - & - \\
\hline$\lambda_{\text {го }}$ & - & - & $(0.78)$ & - & $\begin{array}{ll}- & - \\
\end{array}$ & - \\
\hline${ }_{E P}$ & - & - & - & $\begin{array}{c}-0.17 \\
(-1.07)\end{array}$ & - & - \\
\hline${ }^{2}$ Lev & - & - & - & - & $\begin{array}{c}0.21 \\
(1.07)\end{array}$ & - \\
\hline$n_{\mathrm{Re}}$ & - & - & - & - & - & $\begin{array}{c}-0.11 \\
(-0.67)\end{array}$ \\
\hline
\end{tabular}

Table 3. Pricing premiums of local market factors by Fama-Macbeth (1973) methodology

\section{The Systematic Pricing of Macroeconomic Factors}

In this section, we will investigate whether macroeconomic factors are systematic pricing factors for stock returns in Hong Kong. We assume these factors as systematic risk factors and estimate a stock's sensitivities (betas) to these factors. We then employ Fama-MacBeth (1973) methodology to test whether these macroeconomic factors are systematic risk factors for stocks in the Hong Kong market in the 1979-2013 period. This methodology is also the 
standard procedure for testing the pricing of macroeconomic factors and has been commonly used for testing macroeconomic variables in the work of Ait-Sahalia, Parker, and Yogo (2004), Santos and Veronesi (2006), Yogo (2006), Da (2009), Savov (2011), Boguth and Kuehn (2013) and Liang (2018). We finally adjust the $t$-statistics according to Newey and West (1987).

At first, we estimate the time-series betas of stocks to the above macroeconomic factors in the following regression using past five-year data. The five-year rolling window is the standard procedure in the literature.

$$
R_{i, \tau}=\alpha_{i, t-1}+\beta_{i, t-1}^{m} M K T X_{\tau}+\beta_{i, t-1}^{h} H M L_{\tau}+\beta_{i, t-1}^{s} S M B_{\tau}+\beta_{i, t-1}^{m} \text { MFactor }_{\tau}+\varepsilon_{i, \tau}, \tau=t-60, \ldots, t-1,
$$

where $M K T X$ is the market factor, $H M L$ is the value factor, and $S M B$ is the size factor and the macroeconomic factor, MFactor, is one of industrial production growth and inflation rate. We then estimate the pricing premium of these macroeconomic factors using the following regression. We then adjust t-statistics Newey and West (1987).

$$
R_{i, t}=\alpha+\beta_{i, t-1}^{m} \lambda_{m}+\beta_{i, t-1}^{h} \lambda_{h}+\beta_{i, t-1}^{s} \lambda_{s}+\beta_{i, t-1}^{m f} \lambda_{m f}, t=0, \ldots, T,
$$

where the $\lambda_{m}, \lambda_{h}$, and $\lambda_{s}$ are the pricing premium of $M K T X, H M L$ and $S M B$. The $\lambda_{m f}$ is the pricing premium of one of the macroeconomic factors MFactor.

As reported in Table 4, we find inflation rate demands a significant negative pricing premium across stocks at $10 \%$ level in Hong Kong. This empirical finding is consistent with the pricing phenomenon in the US documented by Chen, Roll, and Ross (1986). The economic rationale and intuition are that high inflation rate hurts the profitability of corporations listed in Hong Kong and increases the funding cost of these corporations. Global investors should pay attention to inflation risk and might use derivatives to hedge inflation risk when they construct their local, regional and global portfolios that include corporations listed in Hong Kong.

This table reports the estimated pricing premium of macroeconomic factors using Fama-Macbeth methodology. The betas of economic factors, MFactor, are estimated from the following regression using past five-year data.

$$
R_{i, \tau}=\alpha_{i, t-1}+\beta_{i, t-1}^{m} M_{\tau} T X_{\tau}+\beta_{i, t-1}^{h} H M L_{\tau}+\beta_{i, t-1}^{s} S M B_{\tau}+\beta_{i, t-1}^{m} \text { MFactor }_{\tau}+\varepsilon_{i, \tau}, \tau=t-60, \ldots, t-1,
$$

The pricing premium are estimated using the following regression.

$$
R_{i, t}=\alpha+\beta_{i, t-1}^{m} \lambda_{m}+\beta_{i, t-1}^{h} \lambda_{h}+\beta_{i, t-1}^{s} \lambda_{s}+\beta_{i, t-1}^{m f} \lambda_{m f}, t=0, \ldots, T,
$$

The macroeconomic factors are inflation rate, industrial growth, and export growth-to-import growth ratio. The adjusted t-statistics are in parentheses. The adjusted t-statistics according to Newey and West (1987) are in parentheses. ${ }^{*}, * *$, and $* * *$ indicate significance at the $10 \%, 5 \%$, and $1 \%$ levels, respectively.

Table 4. Pricing premiums of macroeconomic factors using Fama-Macbeth (1973) methodology

\begin{tabular}{ccc}
\hline & Model 1 & Model 2 \\
\hline$\lambda^{m}$ & 0.07 & 0.16 \\
& $(0.25)$ & $(0.54)$ \\
$\lambda^{h}$ & $0.20^{*}$ & 0.16 \\
& $(1.77)$ & $(1.46)$ \\
$\lambda^{s}$ & 0.27 & $0.33^{*}$ \\
$\lambda_{C P I}$ & $(1.40)$ & $(1.74)$ \\
& $-0.02^{*}$ & - \\
$\lambda_{I P}$ & $(-1.73)$ & $-0.76^{* *}$ \\
& & $(-1.96)$
\end{tabular}

On the other hand, our tests show that the unexpected industrial production growth has a significant and negative pricing premium for stocks in Hong Kong.(Note 10)This is inconsistent with the implication of asset pricing theories we discussed in section 2 and with finding in the US documented by Chen, Roll, and Ross (1986). We interpret that the cross-sectional stock performance does not capture and reflect the industrial production growth in Hong Kong because a large number of corporations listed in Hong Kong Stock Exchange are Chinese corporations whose business activities are in mainland China. Therefore, we treat that the industrial production growth is not a pricing 
factor across stocks in Hong Kong because it has a wrong sign and inconsistent with asset pricing theories and macroeconomic rationale and intuition that we discussed in section 2.

\section{Predictability of Stock Returns}

In this section, we investigate the predictability of stock returns based on betas of systematic factors and a stock's characteristics in Hong Kong stock market. At first, we employ Fama and French's (1992) portfolio sorting procedure to sort stocks in the Hong Kong stock market into five portfolios based on a stock's characteristics. They are market capitalization (size), past one-month returns (short-term reversal), past six-month returns (momentum), a stock's total volatility and idiosyncratic volatility, book-to-market ratio, cash-flow yield, earnings yield, leverage yield, and dividend yield. We calculate both equal-weighted and value-weighted portfolios. We calculate the profitability of the portfolios sorted on the highest (or lowest) value of the characteristics. We then construct the zero-cost portfolios (H-L) that long the portfolios with the highest values of these variables and short the portfolios with the lowest values of these variables. We also calculate one-dollar (\$1) payoff of the portfolios sorted on the top $20 \%$ of the characteristics. We then regress the H-L zero-cost portfolios on multi-factor asset-pricing models to check if there are any significant risk-adjusted excess returns (alphas). At last, we employ Fama-MacBath (1973) regressions to investigate what is the strongest predictor of stock returns in Hong Kong. We adjust the $t$-statistics according to Newey and West (1987).

\subsection{Returns of Portfolios Based on a Stock's t-1 Characteristic}

As reported in Table 5, we find that the high (5) portfolios sorted on book-to-market ratio, dividend yield, earnings yield, and cash-flow yield have significant higher one-month future returns at $1 \%$ level. We also find that the equal-weighted high (5) portfolios sorted on momentum and return-reversal also have higher one-month returns. We then further examine whether the H-L zero-cost portfolios sorted on these characteristics can generate significant risk-adjusted excess returns (alphas) in multi-factor asset-pricing models. We also see how these high portfolios perform against the market portfolio in a period of time by checking one-dollar cumulative payoff invested in these portfolios.

All stocks in are Hong Kong stock exchange are sorted into five portfolios each month based on book-to-market, dividend yield, earning-to-price, cash flow-to-price, leverage-to-price, market value, short-term reversal (past one-month return), momentum (past six-month return), total volatility, and idiosyncratic volatility in 1980-2013. We calculate the equal- and value-weighted return of each portfolio. We also construct the zero-cost portfolio that longs the highest value of these measures and shorts the lowest value of them. The adjusted t-statistics according to Newey and West (1987) are in parentheses. *, **, and $* * *$ indicate significance at the $10 \%, 5 \%$, and $1 \%$ levels, respectively.

Table 5. Returns of Portfolios Constructed on a stock's characteristics

\begin{tabular}{|c|c|c|c|c|c|c|c|c|c|c|}
\hline \multicolumn{11}{|c|}{ Portfolio Returns } \\
\hline \multirow[t]{2}{*}{ Portfolio } & \multicolumn{2}{|c|}{ Earnings Yield } & \multicolumn{2}{|c|}{ Cash-Flow Yield } & \multicolumn{2}{|c|}{ Dividend Yield } & \multicolumn{2}{|c|}{ Book to Market } & \multicolumn{2}{|c|}{ Leverage Yield } \\
\hline & $e w \_r e t$ & $v w \_r e t$ & $e w \_r e t$ & $v w_{-} r e t$ & ew_ret & $v w_{-} r e t$ & $e w \_r e t$ & $v w \_r e t$ & ew_ret & $v w_{-} r e t$ \\
\hline 1 & 0.31 & 0.19 & -0.20 & -0.36 & -0.04 & 0.05 & 0.57 & 0.89 & 1.42 & 1.19 \\
\hline 2 & 0.89 & 0.96 & 0.56 & 0.95 & 1.32 & 1.16 & 1.14 & 1.54 & 1.75 & 1.71 \\
\hline 3 & 1.59 & 1.57 & 1.46 & 1.50 & 1.60 & 1.40 & 1.58 & 1.89 & 1.72 & 1.58 \\
\hline 4 & 2.35 & 2.21 & 2.53 & 2.51 & 2.09 & 1.75 & 1.82 & 1.79 & 1.75 & 1.46 \\
\hline 5 & 2.60 & 2.22 & 3.30 & 2.47 & 2.53 & 2.37 & 2.61 & 2.08 & 1.23 & 1.06 \\
\hline \multirow[t]{3}{*}{$5-1$} & $2.29 * * *$ & $2.03 * * *$ & $3.53 * * *$ & $2.85^{* * * *}$ & $2.67 * * *$ & $2.36 * * *$ & $2.04 * * *$ & $1.19 * * *$ & 0.19 & 0.12 \\
\hline & $(9.22)$ & $(6.79)$ & (12.74) & $(8.46)$ & $(6.30)$ & $(4.85)$ & (7.33) & (4.16) & $(0.72)$ & $(0.35)$ \\
\hline & \multicolumn{2}{|c|}{ Market Value } & \multicolumn{2}{|c|}{ Short term Reversal } & \multicolumn{2}{|c|}{ Momentum } & \multicolumn{2}{|c|}{ Total Vol. } & \multicolumn{2}{|c|}{ Idiosyncratic Vol. } \\
\hline 1 & 1.09 & 1.07 & 0.83 & 0.85 & 0.67 & 0.97 & 0.45 & 0.83 & 0.48 & 0.84 \\
\hline 2 & 1.13 & 1.09 & 0.74 & 1.07 & 0.89 & 1.06 & 1.26 & 1.22 & 1.47 & 1.51 \\
\hline 3 & 1.07 & 1.09 & 0.97 & 1.03 & 1.24 & 1.44 & 1.49 & 1.39 & 1.50 & 1.30 \\
\hline 4 & 1.06 & 1.07 & 1.12 & 1.08 & 1.55 & 1.38 & 1.57 & 1.49 & 1.33 & 1.18 \\
\hline 5 & 1.36 & 1.15 & 1.70 & 1.01 & 1.79 & 1.36 & 0.93 & 0.76 & 0.92 & 0.51 \\
\hline \multirow[t]{2}{*}{$5-1$} & 0.28 & 0.07 & $0.86^{* * *}$ & 0.16 & $1.12 * * *$ & 0.39 & 0.48 & -0.07 & 0.45 & -0.33 \\
\hline & $(0.99)$ & $(0.25)$ & $(2.59)$ & $(0.42)$ & $(3.04)$ & $(0.91)$ & (1.09) & $(-0.18)$ & $(1.12)$ & $(-0.93)$ \\
\hline
\end{tabular}




\subsection{One-Dollar Payoff of Portfolios Based on a Stock's t-1 Characteristic}

We then calculate the one-dollar (\$1) payoff of these value-weighted portfolios of the highest value of a stock's characteristics and the market portfolio from January 1990 to December 2013 and then plot it in Figure 1. (Note 11) As reported in Figure 1, we find that the portfolios formed on a stock's value measures that cash-flow yield, earnings yield, dividend yield and book-to-market ratio have a superior performance against the market portfolio and other portfolios constructed on a stock's other characteristics. The cash-flow yield portfolio generates over 2300 times of $\$ 1$ payoff over 23 years and is the highest payoff portfolio while earnings yield portfolio, dividend portfolio and book-to-market portfolio performed better than other portfolios constructed on other characteristics. This evidence suggests that a stock's value rewards investors the greatest payoff when they construct their portfolios based on these value measures. We also find similar results for other periods starting 1980. We then check if zero-cost portfolios based on a stock's characteristics generate significant excess returns (alphas) adjusted for market factors after controlling for market risk factors in a multi-factor model.

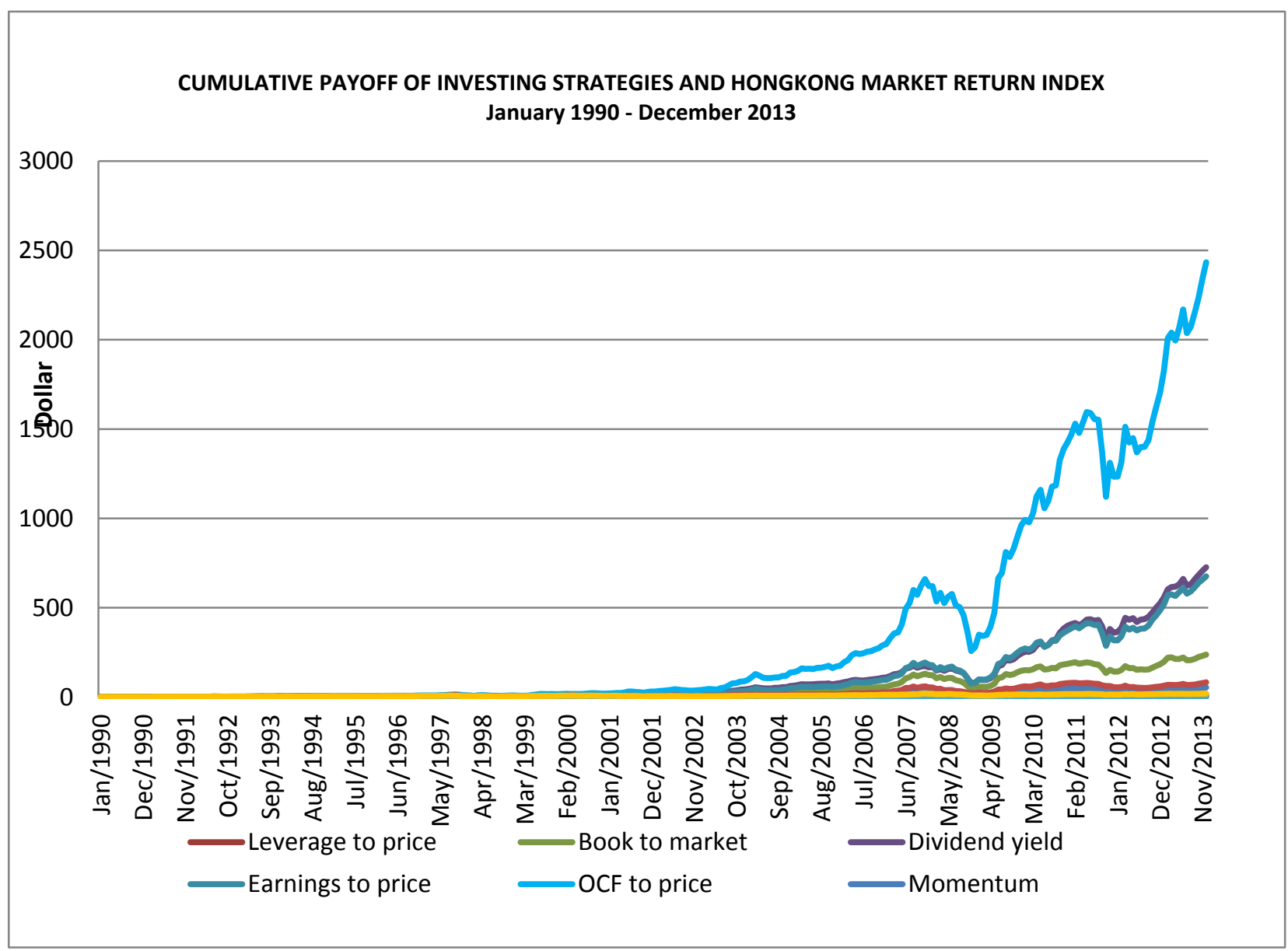

Figure 1. Cumulative Payoff of \$1 Invested in Hong Kong's Total Market Index and in Portfolios with the Highest Size, Momentum, Reversal, Total Volatility, Idiosyncratic Volatility, Book-to-Market, Dividend Yield, Earnings to

Price (Earnings Yield), Cash-Flow to Price (Cash-Flow Yield), and Leverage-to-Price (Leverage Yield) with Monthly Portfolio Rebalancing in the Hong Kong Stock Market.

\subsection{Alphas of Portfolios Constructed by a Stock's $t$-1 Characteristic}

We regress the zero-cost (H-L) portfolios on CAPM and the three-factor model in Hong Kong stated in the following equation (9):

$$
R_{i, \tau}=\alpha_{i, t-1}+\beta_{i, t-1}^{m} M K T X_{\tau}+\beta_{i, t-1}^{h} H M L_{\tau}+\beta_{i, t-1}^{s} S M B_{\tau}+\varepsilon_{i, \tau},
$$


where $\quad r_{i, \tau}$ is the return of portfolio $i$ minus the one-month risk-free rate, MKTX is the market factor, $H M L$ is the value factor, and $S M B$ is the size factor. A three-factor model combines the market, value and size factors. As reported in Table 6, we find that portfolios constructed on a stock's value measures (book-to-market ratio, dividend yield, earnings yield, and cash-flow yield) can generate significant positive alphas. These results further suggest that a stock's value can generate risk-adjusted excess returns for portfolios constructed on these value measures. Portfolios sorted market value also generate significant negative alphas. The reason for the negative alphas is because small stocks outperformed large stocks. The equal-weighted portfolio momentum also generates positive alphas. These results suggest that a stock's characteristics might be able to predict stock returns. We need to employ Fama-MacBath (1973) regressions to further test whether they can predict stock returns after controlling for market risk factors and macroeconomic factors.

All stocks are sorted into five portfolios on their firm-level characteristics that are book-to-market, dividend yield, earnings yield, cash-flow yield, leverage yield, market value (size), short-term reversal (past one-month return), momentum (past six-month return), total volatility, and idiosyncratic volatility in 1980-2013. We calculate the equaland value-weighted return of each portfolio. We also construct the zero-cost portfolio that longs the highest value of these measures and shorts the lowest value of them. Panel A and B reports their alphas in the following multi-factor models in 1975-2013.

$$
R_{i, \tau}=\alpha_{i, t-1}+\beta_{i, t-1}^{m} M K T X_{\tau}+\beta_{i, t-1}^{h} H M L_{\tau}+\beta_{i, t-1}^{s} S M B_{\tau}+\varepsilon_{i, \tau},
$$

The 1-factor model includes the market factor MKTX. The 3-factor model includes Fama-French value factor $H M L$ and size factor $S M B$. The adjusted t-statistics are in parentheses. The adjusted t-statistics according to Newey and West (1987) are in parentheses. $* * *$, and $* * *$ indicate significance at the $10 \%, 5 \%$, and $1 \%$ levels, respectively.

Table 6. Risk-Adjusted Excess Returns (Alphas) of portfolios constructed by a stock's characteristics

Alphas of Multi-Factor Model

\begin{tabular}{|c|c|c|c|c|c|c|c|c|c|c|}
\hline \multirow{2}{*}{$\begin{array}{c}\text { i-Factor } \\
\text { Model }\end{array}$} & \multicolumn{2}{|c|}{ Earnings Yield } & \multicolumn{2}{|c|}{ Cash-Flow Yield } & \multicolumn{2}{|c|}{ Dividend Yield } & \multicolumn{2}{|c|}{ Book to Market } & \multicolumn{2}{|c|}{ Leverage Yield } \\
\hline & ew & $v w$ & ew & $v w$ & ew & ew & $v w$ & $e w$ & $v w$ & ew \\
\hline \multirow[t]{2}{*}{1} & $1.40 * * *$ & $1.91 * * *$ & $2.43 * * *$ & $2.98 * * *$ & $1.83 * * *$ & $2.48 * * *$ & $2.41 * * *$ & $1.16 * * *$ & 0.21 & -0.12 \\
\hline & $(4.27)$ & $(5.43)$ & (7.03) & $(8.40)$ & $(4.53)$ & $(5.29)$ & $(8.52)$ & $(3.92)$ & $(0.77)$ & $(-0.32)$ \\
\hline \multirow[t]{3}{*}{3} & $1.77 * * *$ & $2.16^{* * *}$ & $2.71 * * *$ & $3.30 * * *$ & $2.36^{* * *}$ & $2.39 * * *$ & $1.81 * * *$ & 0.20 & -0.31 & $-1.26^{* * *}$ \\
\hline & $(6.27)$ & $(6.59)$ & (9.04) & $(9.83)$ & $(6.82)$ & (5.39) & $(7.25)$ & $(1.42)$ & $(-1.26)$ & $(-4.29)$ \\
\hline & \multicolumn{2}{|c|}{ Market Value } & \multicolumn{2}{|c|}{ Short-term Reversal } & \multicolumn{2}{|c|}{ Momentum } & \multicolumn{2}{|c|}{ Total Vol. } & \multicolumn{2}{|c|}{ Idiosyncratic Vol. } \\
\hline \multirow[t]{2}{*}{1} & $-2.56 * * *$ & $-1.95 * * *$ & 0.37 & 0.52 & $0.73 *$ & 0.65 & $0.93 * *$ & -0.59 & $1.04 * *$ & -0.58 \\
\hline & $(-6.29)$ & $(-4.72)$ & $(1.00)$ & $(1.27)$ & $(1.86)$ & $(1.38)$ & $(2.07)$ & $(-1.37)$ & $(2.36)$ & $(-1.39)$ \\
\hline \multirow[t]{2}{*}{3} & $-1.41 * * *$ & $-0.44 * * *$ & 0.46 & $0.78^{*}$ & $1.08 * * *$ & $1.04 * *$ & -0.31 & $-1.40 * * *$ & -0.22 & $-1.32 * * *$ \\
\hline & $(-6.67)$ & $(-3.00)$ & $(1.22)$ & (1.86) & $(2.76)$ & $(2.21)$ & $(-0.97)$ & $(-3.58)$ & $(-0.74)$ & $(-3.51)$ \\
\hline
\end{tabular}

6.4 The Cross-Sectional Predictability after Controlling for Market Risk Factors

In this sub-section, we employ a multiple regression approach in Kent and Titman (1997) and Kent, Titman, and Wei (2001) to investigate how a stock's characteristics compete with local market risk factors and macroeconomic factors in predicting stock returns in the Hong Kong market. This multiple regression approach is Fama-MacBath (1973) cross-sectional regressions and the standard procedure for testing cross-sectional predictability of stock returns. We first test the predictability of stock returns based on a stock's characteristics after controlling for market risk factors. These characteristics are the same we use to construct portfolios in previous subsections. The market risk factors are Fama and French three factors because we find that only these three factors are significant pricing factors in Hong Kong in section 4.

We obtain the betas of Fama and French three factors are estimated from the following regression using past five-year data. The five-year rolling window is the standard procedure of estimating the betas. The minimum length is one year.

$$
R_{i, \tau}=\alpha_{i, t-1}+\beta_{i, t-1}^{m} M K T X_{\tau}+\beta_{i, t-1}^{h} H M L_{\tau}+\beta_{i, t-1}^{s} S M B_{\tau}+\varepsilon_{i, \tau}, \tau=t-60, . ., t-1,
$$


where the local market risk factors are market factor $(M K T X)$, book-to-market factor $(H M L)$, and size factor $(S M B)$. We add the characteristics of a stock in the following cross-sectional regression one-by-one as stated in equation (11).

$$
R_{i, t}=\alpha+\beta_{i, t-1}^{m} \lambda_{m}+\beta_{i, t-1}^{h} \lambda_{h}+\beta_{i, t-1}^{s} \lambda_{s}+\beta_{i, j, t-1}^{c h} C h_{i, j, t-1,} t=0, \ldots ., T .
$$

where the betas of market factors are estimated in equation (10) and the $\lambda_{m}, \lambda_{h}$, and $\lambda_{s}$ are the pricing premium of $M K T X, H M L$, and SMB. These market factors are market factor (MKTX), book-to-market factor (HML), and Size (SMB). Ch is one of a stock's characteristics which are market capitalization (MV), book-to-market ratio (BM), cash-flow yield (OCF), short-term reversal (REV), dividend yield (DY), earnings yield (EP), idiosyncratic volatility (IDVOL), total volatility (TVOL), leverage yield (LEV).

We then include all these characteristics except total volatility with three local market risk factors in our pooled regressions as stated in equation (12) because total volatility and idiosyncratic volatility are highly correlated and capture the same risk. We later replace idiosyncratic volatility with total volatility to re-run the regressions.

$$
R_{i, t}=\alpha+\beta_{i, t-1}^{m} \lambda_{m}+\beta_{i, t-1}^{h} \lambda_{h}+\beta_{i, t-1}^{s} \lambda_{s}+\sum_{j=1}^{k} \beta_{i, j, t-1}^{c h} C h_{i, j, t-1}, t=0, \ldots ., T .
$$

The adjusted $t$-statistics according to Newey and West (1987) are in parentheses.

As reported in Table 7, we find that book-to-market ratio and cash-flow yield significantly predict stock returns by itself at $1 \%$ level after controlling for market risk factors when one characteristic is included in the regression. When we include all characteristics in one pooled cross-sectional regression, we find that only book-to-market ratio and cash-flow yield can still significantly predict stock returns at $1 \%$ level. (Note 12)These results suggest that we accept both characteristic and factor models for book-to-market ratio and characteristic model for cash-flow yield. On the other hand, both total volatility, idiosyncratic volatility, momentum, short-term reversal, dividend yield, earnings yield, and leverage yield do not have significant pricing premium as a predictor in the pooled regressions (Note 13)This result suggests that a stock's value measured by book-to-market ratio and cash-flow yield is the strongest predictor for stock returns in Hong Kong stock market. Our results show that the cheap pricing of a stock's fundamentals measured by its book value and cash-flow is the most important predictor of stock returns in Hong Kong stock market. This finding is consistent with the Cakici, Chan, and Topyan's (2015) finding for Chinese stocks listed in Shanghai and Shenzhen Stock Exchanges. They report that the "cheapness" of a stock's value is the most important predictor for stocks listed in Shanghai and Shenzhen Stock Exchanges in China. One of the economic rationales behind this phenomenon is that there is a large number of Chinese corporations listed in Hong Kong Stock Exchange. Another rationale is that the pricing of a stock's fundamentals is the most important predictor for returns of stocks listed in both China and Hong Kong.

This table reports the pricing premium of a stock's characteristics after controlling for market risk factors in 1980-2013. The betas of Fama and French three factors are estimated from the following regression using past five-year data.

$$
R_{i, \tau}=\alpha_{i, t-1}+\beta_{i, t-1}^{m} M K T X_{\tau}+\beta_{i, t-1}^{h} H M L_{\tau}+\beta_{i, t-1}^{s} S M B_{\tau}+\varepsilon_{i, \tau}, \tau=t-60, . ., t-1,
$$

The pricing premiums are the following regression.

$$
R_{i, t}=\alpha+\beta_{i, t-1}^{m} \lambda_{m}+\beta_{i, t-1}^{h} \lambda_{h}+\beta_{i, t-1}^{s} \lambda_{s}+\sum_{j=1}^{k} \beta_{i, j, t-1}^{c h} C h_{i, j, t-1}, t=1, \ldots, T
$$

The local market risk factors are market factor $(M K T X)$, book-to-market factor $(H M L)$, and Size $(S M B)$. Ch is one of a stock's characteristics which are market capitalization (MV), book-to-market ratio $(B M)$, cash-flow yield $(O C F)$, short-term reversal $(R E V)$, dividend yield $(D Y)$, earnings yield ratio $(E P)$, idiosyncratic volatility (IDVOL), total volatility $(T V O L)$, leverage-to-price ratio $(L E V)$. The adjusted t-statistics are in parentheses. The adjusted t-statistics according to Newey and West (1987) are in parentheses. *, **, and *** indicate significance at the $10 \%, 5 \%$, and $1 \%$ levels, respectively. 
Table 7. The Predictability of Stock Returns controlling for Market Risk Factors

\begin{tabular}{|c|c|c|c|c|c|c|c|c|c|c|c|c|}
\hline & & Pri & ing pre & niums & fter co & trollin & for loc & l mark & risk fa & tors & & \\
\hline Model & 1 & 2 & 3 & 4 & 5 & 6 & 7 & 8 & 9 & 10 & 11 & 12 \\
\hline & 0.06 & 0.09 & 0.27 & -0.13 & -0.07 & 0.09 & 0.11 & 0.00 & -0.05 & -0.01 & -0.27 & -0.25 \\
\hline$\Lambda_{m}$ & $(0.21)$ & $(0.27)$ & $(0.81)$ & $(-0.48)$ & $(-0.25)$ & $(0.25)$ & $(0.34)$ & $(-0.01)$ & $(-0.18)$ & $(-0.03)$ & $(-0.82)$ & $(-0.78)$ \\
\hline & 0.15 & 0.03 & 0.10 & 0.15 & 0.17 & 0.07 & 0.10 & 0.18 & 0.17 & 0.10 & -0.03 & -0.07 \\
\hline$\lambda_{h}$ & (1.29) & $(0.22)$ & $(0.66)$ & $(1.40)$ & $(1.51)$ & $(0.49)$ & $(0.68)$ & (1.58) & (1.52) & $(0.70)$ & $(-0.14)$ & $(-0.34)$ \\
\hline & 0.27 & 0.31 & 0.33 & $0.36^{*}$ & $0.36^{* *}$ & $0.36^{*}$ & $0.37 *$ & 0.15 & 0.15 & $0.38^{*}$ & $0.34 *$ & 0.31 \\
\hline$\lambda_{S}$ & (1.53) & $(1.56)$ & (1.64) & $(1.90)$ & $(1.98)$ & $(1.77)$ & $(1.81)$ & $(0.91)$ & $(0.91)$ & $(1.90)$ & (1.72) & $(1.51)$ \\
\hline & 0.00 & & & & & & & & & & 0.00 & 0.00 \\
\hline$\Lambda_{m v}$ & $(0.21)$ & - & - & - & - & - & - & - & - & - & $(0.24)$ & $(0.47)$ \\
\hline$\lambda_{0}$ & & $0.32 * * *$ & & & & & & & & & $0.18^{* * *}$ & $0.17 * * *$ \\
\hline$\lambda_{B M}$ & - & (4.09) & - & - & - & - & - & - & - & - & (2.79) & $(2.54)$ \\
\hline & & & $0.84 * * *$ & & & & & & & & $1.32 * * *$ & $1.38^{* * * *}$ \\
\hline$\lambda_{O C F}$ & - & - & $(3.85)$ & - & - & - & - & - & - & - & (2.74) & (2.87) \\
\hline & & & & 0.36 & & & & & & & 0.02 & 0.24 \\
\hline$\lambda_{R e v}$ & - & - & - & $(0.41)$ & - & - & - & - & - & - & $(0.01)$ & $(0.16)$ \\
\hline & & & & & 0.06 & & & & & & 0.18 & 0.13 \\
\hline$\lambda_{\text {mom }}$ & - & - & - & - & $(0.22)$ & - & - & - & - & - & $(0.44)$ & $(0.32)$ \\
\hline & & & & & & 1.86 & & & & & 1.57 & 0.32 \\
\hline$\lambda_{D Y}$ & - & - & - & - & - & $(1.17)$ & - & - & - & - & $(0.38)$ & $(0.08)$ \\
\hline$\lambda$ & & & & & & & 0.52 & & & & -0.33 & -0.12 \\
\hline$\lambda_{E P}$ & - & - & - & - & - & - & $(0.61)$ & - & - & - & $(-0.16)$ & $(-0.05)$ \\
\hline & & & & & & & & $15.95^{* *}$ & & & 3.57 & \\
\hline$\Lambda_{\text {IdioVo }}$ & - & - & - & - & - & - & - & $(2.41)$ & - & - & $(0.39)$ & - \\
\hline & & & & & & & & & $17.35^{* * *}$ & & & 1.85 \\
\hline$\lambda_{\text {TVol }}$ & - & - & - & - & - & - & - & - & (2.64) & - & - & $(0.20)$ \\
\hline & & & & & & & & & & -0.16 & -0.27 & -0.19 \\
\hline$\Lambda_{L e v}$ & - & - & - & - & - & - & - & - & - & $(-0.47)$ & $(-0.81)$ & $(-0.47)$ \\
\hline
\end{tabular}

6.5 The Cross-Sectional Predictability after Additionally Controlling for Macroeconomic Factors

As we find that inflation rate and industrial production growth have a significant pricing premium across stocks in Hong Kong in section 5. We will include these factors one-by-one to check if a stock's value is still the strongest predictor for stock returns after additionally controlling for market risk factors and macroeconomic factors. In our first step, we estimate the betas of local market factors and MFactor in the following regression using past five-year data with one-year minimum. This five-year rolling window is a standard procedure in estimating betas for Fama-MacBath regressions in the literature.

$$
R_{i, \tau}=\alpha_{i, t-1}+\beta_{i, t-1}^{m} M K T X_{\tau}+\beta_{i, t-1}^{h} H M L_{\tau}+\beta_{i, t-1}^{s} S M B_{\tau}+\beta_{i, t-1}^{m} \text { MFactor }_{\tau}+\varepsilon_{i, \tau}, \tau=t-60, . ., t-1,
$$

where the local factors are market factor $(M K T X)$, book-to-market factor $(H M L)$, size factor $(S M B)$ and $M F a c t o r$, is either industrial production growth or inflation rate. We include Fama and French three factors only because of our findings in section 4 .

We then investigate how a stock's characteristics compete with the above local market risk factors and macroeconomic factors by using the following Fama-MacBeth regression:

$$
R_{i, t}=\alpha+\beta_{i, t-1}^{m} \lambda_{m}+\beta_{i, t-1}^{h} \lambda_{h}+\beta_{i, t-1}^{s} \lambda_{s}+\beta_{i, t-1}^{m f} \lambda_{m f}+\sum_{j=1}^{k} \beta_{i, j, t-1}^{c h} C h_{i, j, t-1}, t=1, \ldots, T
$$


where the $\lambda_{m}, \lambda_{h}$, and $\lambda_{s}$ are the pricing premium of $M K T X, H M L$, and $S M B$. The $\lambda \mathrm{mf}$ is the pricing premium of the macroeconomic factor MFactor. Ch is one of a stock's characteristics which are market capitalization (MV), book-to-market ratio (BM), cash-flow yield (OCF), short-term reversal (REV), dividend yield (DY), earnings yield (EP), idiosyncratic volatility (IDVOL), total volatility (TVOL), leverage yield (LEV). We test one characteristic with this four-factor model at a time and then add all these characteristics except total volatility in one pooled regression. We also replace the idiosyncratic volatility with total volatility in another regression. We adjust $t$-statistics according to Newey and West (1987).

As reported in table 8, we find a stock's value (book-to-market ratio and cash-flow yield) still significantly predict stock returns and is the strongest predictor even after we control for market risk factors and industrial growth and inflation rate. Its predicting power is also at $1 \%$ level. The beta of size factor is also significant at $5 \%$ level in the pooled regression. We also find that earnings yield also has a significant pricing premium at $10 \%$ level when we additionally include macroeconomic factors. Therefore, this value measure can also predict stock returns in a pooled regression that included inflation rate and industrial production growth. Overall, our results show that a stock's value measured by its book-to-market ratio and cash-flow yield is the strongest predictor for stock returns in Hong Kong. Again, our results together with the results in Cakici, Chan, and Topyan (2015) show that the most important cross-sectional predictor for Chinese stocks' returns is the cheap pricing of a stock's fundamentals measured by its book value and cash-flow regardless whether the stocks are listed in Hong Kong Stock Exchange or Shanghai and Shenzhen Stock Exchanges. All these findings suggest that a stock's fundamentals and their cheap pricing are more important than the regulations of stock exchanges and their participants. This is because 1) Hong Kong Stock Exchange has regulations that are significantly different from the regulations of Shanghai and Shenzhen Stock Exchanges, 2) Chinese stock market is classified as an emerging market while Hong Kong Stock market is classified as a developed market by Morgan Stanley Capital International (MSCI) and 3) Chinese Stock Exchanges are mainly restricted to China's domestic investors while Hong Kong Stock Exchange is opened to global investors.

This table reports the pricing premium of a stock's characteristics after controlling for market risk factors and macroeconomic factors which are industrial production growth and inflation rate in 1980-2013. The betas of Fama and French three factors and macroeconomic factors are estimated from the following regression using past five-year data.

$$
R_{i, \tau}=\alpha_{i, t-1}+\beta_{i, t-1}^{m} M K T X_{\tau}+\beta_{i, t-1}^{h} H M L_{\tau}+\beta_{i, t-1}^{s} S M B_{\tau}+\beta_{i, t-1}^{m} \text { MFactor }_{\tau}+\varepsilon_{i, \tau}, \tau=t-60, . ., t-1,
$$

The pricing premiums are the following regression.

$$
R_{i, t}=\alpha+\beta_{i, t-1}^{m} \lambda_{m}+\beta_{i, t-1}^{h} \lambda_{h}+\beta_{i, t-1}^{s} \lambda_{s}+\beta_{i, t-1}^{m f} \lambda_{m f}+\sum_{j=1}^{k} \beta_{i, j, t-1}^{c h} C h_{i, j, t-1}, t=1, \ldots, T
$$

The local market risk factors are market factor $(M K T X G)$, book-to-market factor $(H M L G)$, and Size $(S M B G)$. Ch is one of a stock's characteristics which are market capitalization (MV), book-to-market ratio $(B M)$, cash-flow yield $(O C F)$, short-term reversal $(R E V)$, dividend yield $(D Y)$, earnings yield ratio $(E P)$, idiosyncratic volatility (IDVOL), total volatility $(T V O L)$, leverage-to-price ratio $(L E V)$. The adjusted t-statistics are in parentheses. In Panel A, the macroeconomic factor is inflation rate. IN Panel B, the macroeconomic factor is industrial production growth. The adjusted t-statistics according to Newey and West (1987) are in parentheses. $*, * *$, and $* * *$ indicate significance at the $10 \%, 5 \%$, and $1 \%$ levels, respectively. 
Table 8. The Predictability of Stock Returns additionally controlling for Macroeconomic Factors

\begin{tabular}{|c|c|c|c|c|c|c|c|c|c|c|c|c|}
\hline \multicolumn{13}{|c|}{ Panel A: Pricing premiums after controlling for local market risk factors and inflation } \\
\hline Model & 1 & 2 & 3 & 4 & 5 & 6 & 7 & 8 & 9 & 10 & 11 & 12 \\
\hline$\lambda_{m}$ & $\begin{array}{c}0.06 \\
(0.22)\end{array}$ & $\begin{array}{c}0.03 \\
(0.09)\end{array}$ & $\begin{array}{c}0.13 \\
(0.41)\end{array}$ & $\begin{array}{c}-0.09 \\
(-0.34)\end{array}$ & $\begin{array}{c}-0.06 \\
(-0.20)\end{array}$ & $\begin{array}{c}-0.04 \\
(-0.13)\end{array}$ & $\begin{array}{c}0.05 \\
(0.16)\end{array}$ & $\begin{array}{c}0.01 \\
(0.02)\end{array}$ & $\begin{array}{c}-0.04 \\
(-0.16)\end{array}$ & $\begin{array}{c}-0.04 \\
(-0.11)\end{array}$ & $\begin{array}{c}-0.24 \\
(-0.80)\end{array}$ & $\begin{array}{c}-0.18 \\
(-0.60)\end{array}$ \\
\hline$\lambda_{h}$ & $\begin{array}{c}0.18 \\
(1.63)\end{array}$ & $\begin{array}{c}0.04 \\
(0.32)\end{array}$ & $\begin{array}{c}0.16 \\
(1.18)\end{array}$ & $\begin{array}{l}0.21 * * \\
(2.01)\end{array}$ & $\begin{array}{c}0.16 \\
(1.48)\end{array}$ & $\begin{array}{c}0.13 \\
(1.02)\end{array}$ & $\begin{array}{c}0.12 \\
(0.96)\end{array}$ & $\begin{array}{l}0.19^{*} \\
(1.71)\end{array}$ & $\begin{array}{l}0.18^{*} \\
(1.68)\end{array}$ & $\begin{array}{c}0.14 \\
(1.11)\end{array}$ & $\begin{array}{c}0.13 \\
(0.87)\end{array}$ & $\begin{array}{c}0.11 \\
(0.75)\end{array}$ \\
\hline$\lambda_{s}$ & $\begin{array}{c}0.25 \\
(1.37)\end{array}$ & $\begin{array}{c}0.32 \\
(1.60)\end{array}$ & $\begin{array}{l}0.36^{*} \\
(1.80)\end{array}$ & $\begin{array}{c}0.30 \\
(1.55)\end{array}$ & $\begin{array}{l}0.33^{*} \\
(1.73)\end{array}$ & $\begin{array}{l}0.35^{*} \\
(1.74)\end{array}$ & $\begin{array}{l}0.35^{*} \\
(1.73)\end{array}$ & $\begin{array}{c}0.11 \\
(0.64)\end{array}$ & $\begin{array}{c}0.11 \\
(0.65)\end{array}$ & $\begin{array}{l}0.35^{*} \\
(1.76)\end{array}$ & $\begin{array}{c}0.43 * * \\
(2.40)\end{array}$ & $\begin{array}{c}0.40 * * \\
(2.18)\end{array}$ \\
\hline$\lambda_{c p}$ & $\begin{array}{l}-0.03^{*} \\
(-1.83)\end{array}$ & $\begin{array}{l}-0.03 \\
(-1.18)\end{array}$ & $\begin{array}{c}-0.02 \\
(-0.72)\end{array}$ & $\begin{array}{l}-0.02^{*} \\
(-1.69)\end{array}$ & $\begin{array}{l}-0.03 * \\
(-1.83)\end{array}$ & $\begin{array}{c}-0.01 \\
(-0.65)\end{array}$ & $\begin{array}{l}-0.02 \\
(-0.82)\end{array}$ & $\begin{array}{l}-0.02 \\
(-1.29)\end{array}$ & $\begin{array}{l}-0.02 \\
(-1.24)\end{array}$ & $\begin{array}{c}-0.02 \\
(-0.85)\end{array}$ & $\begin{array}{l}-0.02 \\
(-0.91)\end{array}$ & $\begin{array}{c}-0.02 \\
(-0.97)\end{array}$ \\
\hline$\lambda_{m v}$ & $\begin{array}{c}0.00 \\
(0.43)\end{array}$ & - & - & - & - & - & - & - & - & - & $\begin{array}{c}0.00 \\
(-1.40)\end{array}$ & $\begin{array}{c}0.00 \\
(-1.16)\end{array}$ \\
\hline$\lambda_{B M}$ & - & $\begin{array}{c}0.30 * * * \\
(5.35)\end{array}$ & - & - & - & - & - & - & - & - & $\begin{array}{c}0.18 * * * \\
(2.82)\end{array}$ & $\begin{array}{c}0.18 * * * \\
(2.76)\end{array}$ \\
\hline$\lambda_{O C F}$ & - & $5=$ & $\begin{array}{c}0.87 * * * \\
(3.83)\end{array}$ & - & - & - & - & - & - & - & $\begin{array}{c}1.51 * * * \\
(2.88)\end{array}$ & $\begin{array}{c}1.56 * * * \\
(2.99)\end{array}$ \\
\hline$\lambda_{R e v}$ & - & - & - & $\begin{array}{c}0.28 \\
(0.33)\end{array}$ & - & - & - & - & - & - & $\begin{array}{c}-0.43 \\
(-0.37)\end{array}$ & $\begin{array}{c}-0.19 \\
(-0.16)\end{array}$ \\
\hline$\lambda_{\text {mom }}$ & - & - & - & (2) & $\begin{array}{c}0.32 \\
(1.09)\end{array}$ & - & - & - & - & - & $\begin{array}{c}0.04 \\
(0.10)\end{array}$ & $\begin{array}{c}-0.01 \\
(-0.03)\end{array}$ \\
\hline$\lambda_{D Y}$ & - & - & - & - & - & $\begin{array}{l}1.70 * * \\
(2.40)\end{array}$ & - & - & - & - & $\begin{array}{l}-2.82 \\
(-1.27)\end{array}$ & $\begin{array}{c}-3.88 \\
(-1.61)\end{array}$ \\
\hline$\lambda_{E P}$ & - & - & - & - & - & - & $\begin{array}{c}0.81 * * * \\
(2.64)\end{array}$ & - & - & - & $\begin{array}{l}1.83^{*} \\
(1.72)\end{array}$ & $\begin{array}{c}2.24 * * \\
(2.02)\end{array}$ \\
\hline$\lambda_{\text {IdioVol }}$ & - & - & - & - & - & - & 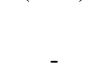 & $\begin{array}{c}15.89 * * \\
(2.34)\end{array}$ & - & - & $\begin{array}{c}1.87 \\
(0.20)\end{array}$ & - \\
\hline $\begin{array}{c}\lambda_{\text {TVol }} \\
\lambda_{\text {Lev }}\end{array}$ & - & - & - & - & - & - & - & - & $\begin{array}{c}-17.29 * * * \\
(2.59)\end{array}$ & $\begin{array}{c}- \\
-0.18 * \\
(-1.65) \\
\end{array}$ & $\begin{array}{c}- \\
-0.15 \\
(-0.91) \\
\end{array}$ & $\begin{array}{c}1.42 \\
(0.16) \\
-0.15 \\
(-0.92) \\
\end{array}$ \\
\hline
\end{tabular}

Panel B: Pricing premium after controlling for local market risk factors and industrial production growth

\begin{tabular}{|c|c|c|c|c|c|c|c|c|c|c|c|c|}
\hline Model & 1 & 2 & 3 & 4 & 5 & 6 & 7 & 8 & 9 & 10 & 11 & 12 \\
\hline$\lambda_{m}$ & $\begin{array}{c}0.14 \\
(0.48)\end{array}$ & $\begin{array}{c}-0.11 \\
(-0.33)\end{array}$ & $\begin{array}{c}0.07 \\
(0.22)\end{array}$ & $\begin{array}{l}-0.02 \\
(-0.06)\end{array}$ & $\begin{array}{c}0.06 \\
(0.21)\end{array}$ & $\begin{array}{c}-0.16 \\
(-0.49)\end{array}$ & $\begin{array}{c}-0.08 \\
(-0.24)\end{array}$ & $\begin{array}{c}0.08 \\
(0.30)\end{array}$ & $\begin{array}{c}0.05 \\
(0.20)\end{array}$ & $\begin{array}{c}-0.13 \\
(-0.39)\end{array}$ & $\begin{array}{c}-0.39 \\
(-1.25)\end{array}$ & $\begin{array}{c}-0.37 \\
(-1.21)\end{array}$ \\
\hline$\lambda_{h}$ & $\begin{array}{c}0.15 \\
(1.33)\end{array}$ & $\begin{array}{c}0.00 \\
(0.03)\end{array}$ & $\begin{array}{c}0.06 \\
(0.42)\end{array}$ & $\begin{array}{c}0.15 \\
(1.43)\end{array}$ & $\begin{array}{c}0.14 \\
(1.26)\end{array}$ & $\begin{array}{c}0.09 \\
(0.69)\end{array}$ & $\begin{array}{c}0.09 \\
(0.69)\end{array}$ & $\begin{array}{c}0.16 \\
(1.43)\end{array}$ & $\begin{array}{c}0.15 \\
(1.36)\end{array}$ & $\begin{array}{c}0.10 \\
(0.79)\end{array}$ & $\begin{array}{c}0.01 \\
(0.09)\end{array}$ & $\begin{array}{c}0.02 \\
(0.10)\end{array}$ \\
\hline$\lambda_{s}$ & $\begin{array}{l}0.31^{*} \\
(1.68)\end{array}$ & $\begin{array}{l}0.39 * \\
(1.88)\end{array}$ & $\begin{array}{c}0.31 \\
(1.50)\end{array}$ & $\begin{array}{c}0.41 * * \\
(2.06)\end{array}$ & $\begin{array}{c}0.38 * * \\
(1.98)\end{array}$ & $\begin{array}{l}0.43 * * \\
(2.10)\end{array}$ & $\begin{array}{l}0.41 * * \\
(2.02)\end{array}$ & $\begin{array}{c}0.18 \\
(1.07)\end{array}$ & $\begin{array}{c}0.17 \\
(1.02)\end{array}$ & $\begin{array}{l}0.40^{*} \\
(1.94)\end{array}$ & $\begin{array}{c}0.46^{* * * *} \\
(2.47)\end{array}$ & $\begin{array}{l}0.44 * * \\
(2.33)\end{array}$ \\
\hline$\lambda_{I P}$ & $\begin{array}{l}-0.73^{*} \\
(-1.88)\end{array}$ & $\begin{array}{c}-0.36 \\
(-0.79)\end{array}$ & $\begin{array}{c}0.05 \\
(0.12)\end{array}$ & $\begin{array}{l}-0.55 \\
(-1.43)\end{array}$ & $\begin{array}{l}-0.55 \\
(-1.46)\end{array}$ & $\begin{array}{c}-0.21 \\
(-0.49)\end{array}$ & $\begin{array}{l}-0.37 \\
(-0.79)\end{array}$ & $\begin{array}{l}-0.55 \\
(-1.54)\end{array}$ & $\begin{array}{l}-0.52 \\
(-1.45)\end{array}$ & $\begin{array}{c}-0.49 \\
(-1.07)\end{array}$ & $\begin{array}{c}0.04 \\
(0.08)\end{array}$ & $\begin{array}{c}0.08 \\
(0.16)\end{array}$ \\
\hline$\lambda_{m v}$ & $\begin{array}{c}0.00 \\
(0.61)\end{array}$ & - & - & - & - & - & - & - & - & - & $\begin{array}{c}0.00 \\
(-0.81)\end{array}$ & $\begin{array}{c}0.00 \\
(-0.10)\end{array}$ \\
\hline$\lambda_{B M}$ & - & $\begin{array}{c}0.29^{* * * *} \\
(5.43)\end{array}$ & - & - & - & - & - & - & - & - & $\begin{array}{c}0.21 * * * * \\
(3.17)\end{array}$ & $\begin{array}{c}0.21 * * * \\
(3.14)\end{array}$ \\
\hline$\lambda_{O C F}$ & - & - & $\begin{array}{c}0.98 * * * \\
(4.11)\end{array}$ & - & - & - & - & - & - & - & $\begin{array}{c}1.39 * * * \\
(2.73)\end{array}$ & $\begin{array}{c}1.39 * * * \\
(2.74)\end{array}$ \\
\hline$\lambda_{R e v}$ & - & - & (1.1, & $\begin{array}{c}0.41 \\
(0.49)\end{array}$ & - & - & - & - & - & - & $\begin{array}{c}-0.49 \\
(-0.42)\end{array}$ & $\begin{array}{c}-0.17 \\
(-0.15)\end{array}$ \\
\hline$\lambda_{\text {mom }}$ & - & - & - & - & $\begin{array}{c}0.23 \\
(0.85)\end{array}$ & - & - & - & - & - & $\begin{array}{l}-0.10 \\
(-0.26)\end{array}$ & $\begin{array}{c}-0.09 \\
(-0.23)\end{array}$ \\
\hline$\lambda_{D Y}$ & - & - & - & - & - & $\begin{array}{l}1.07 * * \\
(2.00)\end{array}$ & - & - & - & - & $\begin{array}{l}-1.17 \\
(-1.06)\end{array}$ & $\begin{array}{l}-1.25 \\
(-1.12)\end{array}$ \\
\hline$\lambda_{E P}$ & - & - & - & - & - & - & $\begin{array}{c}0.42^{* * * *} \\
(2.85)\end{array}$ & - & - & - & $\begin{array}{l}1.15^{*} \\
(1.78)\end{array}$ & $\begin{array}{l}1.22 * \\
(1.86)\end{array}$ \\
\hline$\lambda_{\text {IdioVol }}$ & - & - & - & - & - & - & - & $\begin{array}{c}15.39 * * \\
(2.26)\end{array}$ & - & - & $\begin{array}{c}2.99 \\
(0.36)\end{array}$ & - \\
\hline $\begin{array}{c}\lambda_{\text {TVol }} \\
\lambda_{\text {Lev }}\end{array}$ & - & - & - & - & - & - & - & - & $\begin{array}{c}16.86^{* * * *} \\
(2.54)\end{array}$ & $\begin{array}{c}- \\
-0.24 * * \\
(-2.36)\end{array}$ & $\begin{array}{c}- \\
0.00 \\
(0.00)\end{array}$ & $\begin{array}{c}2.84 \\
(0.36) \\
-0.02 \\
(-0.14)\end{array}$ \\
\hline
\end{tabular}




\section{Conclusion}

We comprehensively investigate what drives stock returns in Hong Kong in the 1979-2013 period. We find that inflation rate is a systematic pricing factor for stock returns in Hong Kong stock market. This is because inflation rate diminishes investment opportunities by raising the cost of operations for corporations listed in Hong Kong stock market. We also find that, unlike in the US and other developed markets, momentum factor, cash-flow yield factor, earnings yield factor, dividend yield factor, and return reversal factor are not systematic pricing factor in Hong Kong stock market. When global investors hedge systematic risks for their portfolios, they should be concerned about Fama-French three factors and the inflation rate risk in Hong Kong.

In addition, we find that a stock's book-to-market and cash-flow yield significantly predict stock returns after controlling market risk factors and macroeconomic factors and that they are the strongest predictors for stock returns in Hong Kong. Global investors should pay more attention to a stock's book-to-market ratio and cash-flow yield when they construct their local, regional and global portfolios that include stocks listed in Hong Kong Stock Exchange. The cheapness of the pricing for a stock's book value and cash flow is the most important factor for picking stocks listed in Hong Kong Stock Exchange. Our concluding message is that the cheap pricing of a stock's fundamentals measured by book value and cash-flow is more important for stock return predictability than the regulations of stock exchanges and their participants. This is because 1) The regulations of Hong Kong Stock Exchange are significantly different from the regulations of Shanghai and Shenzhen Stock Exchanges, 2) Chinese stock market is an emerging market while Hong Kong Stock market is a developed market and 3) Chinese Stock Exchanges are mainly accessible to China's domestic investors while Hong Kong Stock Exchange is accessible to global investors.

\section{Acknowledement}

We thank Nusret Cakici, Kalok Chan, Nai-Fu Chen, Gang Li, Cen Ling, Raymond Kan, Mark Seasholes, Sheridan Titman and K.C. John Wei for their helpful comments and discussions. We also thank Man Yin Cheuk for her excellent research assistant. Normal disclaimers apply.

\section{References}

Ait-Sahalia, Yacine, Jonathan A. Parker \& Motohiro Yogo. (2004). Luxury Goods and the Equity Premium. Journal of Finance, 59, 6, 2959-3004, https://doi.org/10.1111/j.1540-6261.2004.00721.x

Ang, Andrew \& Geert Bekaert. (2007). Stock return predictability: Is it there? Review of Financial Studies, 20, 3, 651-707. https://doi.org/10.1093/rfs/hhl021

Ang, Andrew, Robert J. Hodrick, Yuhang Xing \& Xiaoyan Zhang. (2006). The cross-section of volatility and expected returns. Journal of Finance, 61, 259-276. https://doi.org/10.1111/j.1540-6261.2006.00836.x

Ang, Andrew, Robert J. Hodrick, Yuhang Xing \& Xiaoyan Zhang. (2009). Higher idiosyncratic volatility and lower expected stock returns: International and further U.S. evidence. Journal of Financial Economics, 91, 1-23. https://doi.org/10.1111/jofi.12058

Boguth, Oliver \& Lars-Alexander Kuehn. (2013). Consumption Volatility Risk. Journal of Finance, 68(6), 2589-2650. https://doi.org/10.1111/jofi.12058

Cakici, Nusret, Kalok Chan \& Kudret Topyan. (2015). Cross-sectional stock return predictability in China. The European Journal of Finance, 23, 581-605. https://doi.org/10.1080/1351847X.2014.997369

Carhart, Mark M. (1997). On persistence in mutual fund performance. Journal of Finance, 52, 57-82. https://doi.org/10.1111/j.1540-6261.1997.tb03808.x

Da, Zhi. (2009). Cash Flow, Consumption Risk, and the Cross-section of Stock Returns. Journal of Finance, 63(2), 923-956. https://doi.org/10.1111/j.1540-6261.2009.01453.x

Fama, Eugene F. \& Kenneth R. French. (1992). The cross-section of expected stock returns. Journal of Finance, 47, 427-465. https://doi.org/10.1111/j.1540-6261.1992.tb04398.x

Fama, Eugene F. \& Kenneth R. French. (1993). Common risk factors in the returns on stocks and bonds. Journal of Financial Economics, 33, 3-56. https://doi.org/10.1016/0304-405X(93)90023-5

Fama, Eugene F. \& Kenneth R. French. (1998). Value versus growth: International evidence. Journal of Finance, 53, 1975-1999. https://doi.org/10.1111/0022-1082.00080

Fama, Eugene F. \& Kenneth R. French. (2012). Size, Value, and Momentum in International Stock Returns. Journal of Financial Economics, 105(3), 457-472. https://doi.org/10.1016/j.jfineco.2012.05.011 
Fama, Eugene. F. \& James D. MacBeth. (1973). Risk, return, and equilibrium: Empirical tests. Journal of Political Economy, 71, 607-636. https://doi.org/10.1086/260061

Hou, Kewei Hou, G. Andrew Karolyi \& Bong-Chan Kho. (2011). What Factors Drive Global Stock Returns? Review of Financial Studies, 24(8), 2527-2574. https://doi.org/10.1093/rfs/hhr013

Huang, Wei, Qianqiu Liu, Rhee S. Ghon \& Liang Zhang. (2010). Return Reversals, Idiosyncratic Risk and Expected Returns. Review of Financial Studies, 23(1), 147-168. https://doi.org/10.1093/rfs/hhp015

Kent, Daniel \& Sheridan Titman. (1997). Evidence on the characteristics of cross-sectional variation in stock returns. Journal of Finance, 52, 1-33. https://doi.org/10.1111/j.1540-6261.1997.tb03806.x

Kent, Daniel, Sheridan Titman \& K.C. John Wei. (2001). Explaining the cross-section of stock returns in Japan: factors or characteristics? Journal of Finance, 56, 743-766. https://doi.org/10.1111/0022-1082.00344

Kubota, Keiichi \& Hitoshi Takehara. (2017). Does the Fama and French Five-Factor Model Work Well in Japan? International Review of Finance, 18(1), 137-146. https://doi.org/10.1111/irfi.12126

Lemmon, Michael \& Thanh Nguyen. (2015). Dividend yields and stock returns in Hong Kong. Managerial Finance, 4l(2), 164-181. https://doi.org/10.1108/MF-01-2014-0009

Liang, Samuel Xin. (2018). The Systematic Pricing of Market Sentiment Shock. The European Journal of Finance, 24(18), 1835-1860, https://doi.org/10.1080/1351847X.2018.1491875.

Liang, Samuel Xin \& K.C. John Wei. (2019). Market Volatility Risk and Stock Returns around the World, International Review of Finance, https://doi.org/10.1111/irfi.12252.

Liang, Samuel Xin. (2019). What Drives Stock Returns in Japan? Financial Markets and Portfolio Management, 33(1), 39-69, https://doi.org/10.1007/s11408-018-0322-7.

Liang, Samuel Xin \& John K.C. Wei. (2012). Liquidity risk and stock returns around the world. Journal of Banking and Finance, 36, 3274-3288. https://doi.org/10.1016/j.jbankfin.2012.07.021

Liu, Laura Xiaolei \& Lu Zhang. (2008). Momentum profits, factor pricing, and macroeconomic risk. Review of Financial Studies, 21(6), 2417-2448. https://doi.org/10.1093/rfs/hhn090

Jegadeesh, Narasimhan. (1993). Evidence of predictable behavior of security returns. Journal of Finance, 45, 881-898. https://doi.org/10.1111/j.1540-6261.1990.tb05110.x

Jegadeesh, Narasimhan \& Titman, Sheridan. (1993). Returns to buying winners and selling losers: implications for stock market efficiency. Journal of Finance, 48, 65-91. https://doi.org/10.1111/j.1540-6261.1993.tb04702.x

Merton, Robert C. (1973). An intertemporal capital asset pricing model. Econometrica, 41, 867-887, https://doi.org/10.2307/1913811

Newey, W \& K. West. (1987). A Simple Positive Definite, Heteroscedasticity and Autocorrelation on Consistent Covariance Matrix. Econometrica, 55, 703-705. https://doi.org/10.2307/1913610

Pástor, Lubos \& Robert F. Stambaugh. (2003). Liquidity risk and expected stock returns. Journal of Political Economy, 111, 642-685. https://doi.org/10.1086/374184

Ritter, R. Jay. (2005). Economic Growth and Equity Returns. Pacific-Basin Finance Journal, 13, 489-503. https://doi.org/10.1016/j.pacfin.2005.07.001

Santos, Tano \& Pietro Veronesi. (2006). Labor Income and Predictable Stock Returns. Review of Financial Studies, 19(1), 1-44. https://doi.org/10.1093/rfs/hhj006

Savov, Alexi. (2011). Asset Pricing with Garbage. Journal of Finance, 66(1), 177-201. https://doi.org/10.1111/j.1540-6261.2010.01629.x.

Yogo, Motohiro. (2006). A Consumption-Based Explanation of Expected Stock Returns. Journal of Finance, 61(2), 539-580. https://doi.org/10.1111/j.1540-6261.2006.00848.x 


\section{Notes}

Note 1. Fama and French (2015) propose two new factors - robust-minus-weak profitability factor and conservative-minus-aggressive investment factor in their five-factor model for stock returns in the USA. However, Kubota and Takehara (2017) show that these two new Fama-French factors are not significant pricing factors across stocks in Japan. The investigation on the pricing premium of these two factors in Hong Kong is out of the scope of this paper.

Note 2. Liang (2019) also has the same results as Ang, Hodrick, Xing, and Zhang (2009) on the negative predictability of a stock's total volatility and idiosyncratic volatility in Japan.

Note 3. The pricing of the market sentiment risk factor is out of the scope of this paper because there is no relevant market sentiment index available in Hong Kong.

Note 4. See Fama and French (1992), Jegadeesh and Titman (1993), Ang, Hodrick, Xing, and Zhang (2006 and 2009), Ang and Bekaert (2007), Huang, Liu, Ghon, and Zhang (2010), and Fama and French (2012).

Note 5. Previous studies include Hong Kong stock market in a topical study for a particular asset pricing issue in Asia Pacific region (see Ang, Hodrick, Xing, and Zhang (2009), Liang and Wei (2012), Fama-French (2012) and Liang and Wei (2019)).

Note 6. The Fama-MacBath (1973) two-stage regression methodology is the standard procedure to test whether a risk factor is a systematic pricing factor in the literature.

Note 7. Ritter (2005) show that per capita GDP growth has a negative cross-country correlation in the 1990-2002 period. We also find that Hong Kong GDP growth has a negative pricing premium across stocks.

Note 8. Santos and Veronesi (2006) also show that labor income, in addition to the market factor, is a systematic pricing factor across Fama and French's (1992) 25 size and value portfolios. Liu and Zhang (2008) also find that a half of momentum profit can be explained by the industrial production risk factor in the U.S. market.

Note 9. The Chinese stock market is not a good proxy for the U.S. stock market Chinese currency is not freely exchangeable even though China relaxed its trading range against the central bank's daily mid-fixing rate in 2005.

Note 10. We also find that GDP growth also has a negative pricing premium across stocks in Hong Kong.

Note 11. There are more stocks starting from January 1990. The portfolios constructed based on size and return reversal are the smallest size portfolio and the lowest return portfolio.

Note 12. The beta of size factor is significant at $10 \%$ level when we include the total volatility but become insignificant we include idiosyncratic volatility.

Note 13. Total volatility and idiosyncratic volatility have significant pricing premiums in the regressions that do not include cash-flow yield, book-to-market ratio and other stock characteristics. 